ination. On leaving Cambridge he worked for a time with Messrs. Kelvin and James White, of Glasgow, on researches relating to electrical and magnetic problems. Later he held, in turn, lectureships in electrical engineering at the Rutherford Technical College, Newcastle-on-Tyne, and at the Borough Polytechnic, London.

In 1915 Tomlinson was appointed to a post at the National Physical Laboratory, where he was first engaged, during the War of 1914-18, on the verification of gauges. From this he turned his attention to devising apparatus for the measurement of gears and gear-cutting hobs, then almost a new field, with which he continued to be closely associated for the rest of his life, developing further methods and instruments for checking the accuracy of gears of all sizes, and of the hobbing machines used in their production. In this subject he became a recognized expert whose advice was sought both by government departments and by private firms.

Among other matters Tomlinson also devoted himself successfully to the study of molecular cohesion in relation to surface phenomena such as pressure corrosion and friction. Following this, he became interested in the geometrical properties of surfaces, and devised the now well-known surface-finish recorder which bears his name, and which is an ex. cellent example of his direct attack on a problem, and his faculty for attaining results by the simplest means.

An altogether different line of work was in connexion with the improvement of time-keepers. $\mathrm{He}$ spent much time on the development of a new type of vibration clock, and in experiments on new methods for driving free pendulum clocks. Incidentally to this work, he designed a new type of chronograph for the comparison of time-signals to an accuracy of 0.1 millisecond.

Tomlinson had a flair for instrument design which amounted to genius. More often than not he would make the first model of a new instrument with his own hands, using the material nearest to hand. But though these first models might have a somewhat gimerack appearance they were always usable tools and, being usually designed to meet some immediate need, were often put into practical service for considerable periods before, as happened in many cases, their proved utility made it desirable to re-design them in a form suitable for commercial production.

Tomlinson-"Tommy" to his friends-had a charming and lovable personality. Modest and unassuming, he was always ready with advice and help for others, and a source of inspiration to those who worked with him. $\mathrm{He}$ was a rare combination of man of science and practical engineer, and his death is a national loss. He leaves a widow and two sons.

J. E. Sears.

\section{Dr. J. N. Sugden}

Dr. J AMES N. SUGDEN, senior lecturer in inorganic chemistry in the Imperial College of Science and Technology, who was killed by a flying bomb on July 11, 1944, was born at Silsden, near Keighley, on March 27, 1894. As a pupil of the Trade and Grammar School, Keighley, he came under the influence of a former student of chemistry in the Royal College of Science, Mr. Harry Harper, and after a period of study at the Technical College, Huddersfield, he proceeded to South Kensington in 1913.
Having graduated as an associate with first-class honours, and having been awarded the Neil Arnott Studentship and a Royal Scholarship, Sugden devoted himself to investigations which naturally soon became closely related to war problems. He received a commission in the Army, and under the direction of the late Prof. H. Brereton Baker he took part in some of the early scientific work which arose out of the enemy's use of poison gas. Later he was much concerned with the technical development of methods and equipment for ensuring an adequate supply of safe drinking water for troops dependent on contaminated supplies, particularly in France and in Mesopotamia. Under his immediate supervision, large mobile and static chlorination plants with their control laboratories were designed, tested, dispatched, and operated. Returning in 1919 from a prolonged visit to Iraq, he was appointed a demonstrator in chemistry at the Royal College of Science (Imperial College of Science and Tochnology); he was promoted to be a lecturer in 1922, and senior lecturer in 1943. There he quickly established a reputation as a most conscientious and efficient teacher.

Sugden's methods were often ingenious, and sometimes unorthodox; for he was an individualist whose acidulated epigrams were a tonic to the laggard, but whose meticulous care and patient instruction were an inspiration to every diligent student. Prolonged ill-health restricted the scope of his physical activity, but his mind seemed the more acute. His principal contribution to chemical knowledge concerned the hydration of salts in aqueous solution. This study yielded most interesting results; but he placed his teaching duties before all other attractions, and never regained the physical strength to pursue the inquiry.

Sugden was not an easy man to know. His bachelor life was lonely, and his friends, deliberately few, scattered by the march of time. He was interested in British silver coins, and liked to try his hand at the more erudite literary competitions in periodicals, especially those involving a foreign language. He was a judge of burgundy, and his efforts as an amateur photographer disclosed an artistic perception. While few could phrase a rebuke more mordantly, few enjoyed more gloomily the humour of life or more often delighted their acquaintances with gleanings among the unusual, the comic, or the profound. By his colleagues, as well as by many of the students to whom he ministered for twenty-five years, he will be remembered with affection and with the respect due to one who, having well considered, possessed the courage of his convictions. A. A. ElDRIDGe.

\section{Prof. B. B. Ray}

Prof. B. B. RAY, Khaira professor of physics in the University of Calcutta, died on July 29, 1944. He was a fellow of the National Institute of Sciences of India; and presided over the Physics Section of the twenty-ninth session of the Indian Science Congress, held at Baroda in 1942. Prof: Ray joined the University of Calcutta in 1921 as a lecturer in physics and was one of the early batch of students who carried out research work in physics under Sir C. V. Raman.

Prof. Ray visited Europe twice, once in 1923 and again in 1935. During his first visit he worked at Uppsala in the laboratory of Prof. M. Siegbahn and at Copenhagen under Prof. Niels Bohr. It was in Prof. Siegbahn's laboratory that Prof. Ray learned 
the technique of research on X-ray spectra. On his return to India he devoted himself to founding an active school of research on X-rays.

In 1935, he was elected to the Khaira chair of physics in the University of Calcutta.

Immediately before his death, Prof. Ray was carrying out researches on the absorption and emission spectra in the soft $\mathrm{X}$-ray region. He was also conducting investigations on the luminescence of solids under X-ray bombardment. Prof. Ray had a charming and lovable personality and was very popular with his students. Science in India has suffered a great loss by his untimely death at the early age of fifty.
We regret to announce the following deaths:

Prof. Edward F. Berry, professor of civil engineering at Syracuse University, on August 28, aged fifty-four.

Prof. E. F. Gaines, professor of genetics in agronomy and cerealist in the Agricultural Experiment Station of the State College of Washington, known for his work on the inheritance of disease resistance in cereals, on August 17, aged fifty-eight.

Dr. Walter L. Jennings, formerly professor of chemistry and later director of the Worcester Poly. technic Institute, Massachusetts, on September 2, aged seventy-seven.

\section{NEWS and VIEWS}

\section{Royal Institute of International Affairs}

The annual report of the Council of the Royal Institute of International Affairs for the year ended June 30,1944 , gives a brief review of the growth of the work since the Institute was established in 1919 for the scientific study of international affairs. A committee was appointed by the Council on April 19, 1944, to review the developments of a quarter of a century, "to re-examine the purposes for which the Institute was founded; to inquire whether any change is desirable in the present activities of Chatham House, or any shift of emphasis in order to increase its influence and value". Researches into international problems published during these twentyfive years appearing in the growing list of volumes under the auspices of the Institute have already placed Chatham House on a footing comparable with the national institutions established in other fields. Strict adherence to the basic rule that the Institute should express no corporate opinion on any aspect. of international affairs has contributed in no small measure to recognition of its integrity and to the attainment of its present position. Means of study have been provided for the serious student of international affairs. The Library is the most comprehensive collection of its kind in England, and has overflowed from its cramped quarters into more ample reading rooms. The Press archives are unique, and after the War, when these archives are returned to Chatham House by the Foreign Office Research Department and again become generally available, they will be a source of information that will attract scholars from all over the world.

With regard to the past year, the report refers to the opening on May 17, 1944, of the additional premises at 9 St. James's Square, London, the republication in January 1944 of International Affairs as a quarterly, by arranging for printing in Canada, and the opening in New York on February 1 of a Publications Office for distribution of the Institute's publications, and to the continuance of week-end courses on international affairs for officers and men of the Forces. A list of the fourteen courses arranged is appended, and the 300 available places at.each were allocated among the Royal Navy, the British Army, Royal Air Force, Canadian Army and U.S. Army. The "British Year-Book of International Law", which was suspended at the outbreak of war, is to re-appear shortly as a Chatham House publication covering the period 1940-43. Reconstruction studies have continued, but only one report, "The
International Secretariat of the Future", was published during the year. A preliminary report of the group dealing with economic and social problems will be published shortly under the title "The Economic Lessons of the Nineteen-Thirties", as well as a series of pamphlets under the title "Looking Forward" to assist members of the general public to form their opinions on some of the principal inter. national problems of reconstruction. One of these, by Dr. C. H. Desch, deals with "Science and the Social Order". Lists of individual studies published during the year, in the press or in progress are included; with notes on Far Eastern studies and the Institute of Pacific Relations, British Commonwealth relations, Allied research in London and on the work of the branches and of the institutes in the Dominions and in India.

\section{Town and Country Planning in Britain}

Bulletin No. 4 of the Tory Reform Committee deals with "Government Policy for the Rebuilding of Urban Areas" as set forth in the Town and Country Planning Act, of which it gives a concise exposition. Development in Great Britain has hitherto been haphazard, uneconomical and unplanned for five reasons. The planning authorities have always been too small and there has been no central machinery co-ordinating local schemes in accordance with a national policy. Any planning authority inclined to take a less parochial view met financial difficulties resulting from its small size. Urban authorities were similarly penalized if they sought to make an enlightened dispersal of their population, because this meant handing rateable value to neighbouring authorities. Again, just where dispersal was most needed, land values rose sharply in proportion to the need for using the land. Compulsory acquisition by an authority was made slow, difficult and costly by the old piecemeal procedure.

The Tory Reform Committee holds that there can be no doubt that the elimination of all local inquiries, except in special cases, as was recommended by the Uthwatt Committee, would greatly expedite the compulsory acquisition of land, but it would be impossible to justify the compulsory purchase of the property of individuals without giving them an adequate opportunity of stating their objections. Again, it would be disastrous if post-war plahning resulted merely in a tidier expansion of the existing industrial aggregations. What is really required is, first, the encouragement of industry into 